\title{
Warning signal: Unaware of an in absentia conviction, South African cancer specialist jailed on return to the United Arab Emirates.
}

\author{
Philip R Cohen \\ Dermatalogist, Bellaire, Texas \\ Razelle Kurzrock \\ Medical Oncologist, Bellaire Texas \\ Lawrence Parish \\ Thomas Jefferson University
}

Follow this and additional works at: https://jdc.jefferson.edu/dcbfp

Part of the Dermatology Commons

\section{Let us know how access to this document benefits you}

\section{Recommended Citation}

Cohen, Philip R; Kurzrock, Razelle; and Parish, Lawrence, "Warning signal: Unaware of an in absentia conviction, South African cancer specialist jailed on return to the United Arab Emirates." (2013). Department of Dermatology and Cutaneous Biology Faculty Papers. Paper 12. https://jdc.jefferson.edu/dcbfp/12

This Article is brought to you for free and open access by the Jefferson Digital Commons. The Jefferson Digital Commons is a service of Thomas Jefferson University's Center for Teaching and Learning (CTL). The Commons is a showcase for Jefferson books and journals, peer-reviewed scholarly publications, unique historical collections from the University archives, and teaching tools. The Jefferson Digital Commons allows researchers and interested readers anywhere in the world to learn about and keep up to date with Jefferson scholarship. This article has been accepted for inclusion in Department of Dermatology and Cutaneous Biology Faculty Papers by an authorized administrator of the Jefferson Digital Commons. For more information, please contact: JeffersonDigitalCommons@jefferson.edu. 


\section{As submitted to:}

\section{Clinics in Dermatology}

\section{And later published as:}

\section{Volume 31, Issue 1, Pages: 128-130, Jan 2013}

\section{doi: 10.1016/j.clindermatol.2012.11.001.}

Warning signal: Unaware of an in absentia conviction, South African cancer specialist jailed on return to the United Arab Emirates

In 2002, Dr. Cyril Karabus, a specialist in pediatric cancers and retired head of the Oncology and Hematology Unit of Red Cross Children's Hospital in Capetown, South Africa, spent a brief locum at Sheikh Khalifa Medical City, a hospital in Abu Dhabi in the United Arab Emirates (UAE). He was there for only 5 weeks, during which time he treated a young girl who died of acute myeloblastic leukemia. After Karabus returned home, the girl's father complained to police about his daughter's death, and Karabus was convicted of murder in absentia. Karabus knew nothing of the charges or of the conviction. Widely respected for his expertise and compassion, Karabus had dedicated his life to treating children with malignancies. In South Africa, he was especially well known for his commitment to saving the lives of black children with cancer during the apartheid era.1

\section{Background}

In August 2012, some 10 years after his short stint in the UAE, the now 77-year-old Karabus was on his way home to South Africa after his son's wedding in Canada. He spent a night in Dubai on a stopover flight and was astonished to be arrested the next morning (August 18, 2012) at passport control. His companions on that flight (his wife, daughter, and son-in-law) had to leave the country because they had only short-term visas. 2

From mid-August to mid-October, Karabus, who suffers from fragile health and a heart condition, languished in a prison in the UAE. His passport was seized. He was seen shackled and hunched in an Abu Dhabi courtroom and appeared broken. He was initially denied bail despite four requests, and his hearings were marred by the fact that the girl's medical files had gone missing. 1,2

The World Medical Association wrote to the UAE justice minister to express its "deep concern about Professor Karabus and the state of his health," as well as its dismay at the UAE's refusal to grant bail.3 The Treatment Action Campaign, a South African activist organization, stated: "by no modern principle of jurisprudence is it acceptable to try a foreign citizen in absentia without informing him."4 Delegates from 50 national medical associations unanimously adopted an 
emergency resolution in support of Karabus.5 The British Medical Association protested the conditions in which the professor was held, and in an editorial, the British Medical Journal called his imprisonment "deplorable."1

The elderly pediatrician's arrest and detention has placed the UAE's judicial system in the spotlight. Nick McGeehan from Human Rights Watch said: "I would say the case is symptomatic of a judicial system which is not particularly effective in delivering justice."6 The UAE's wealth and economic clout belies its widely criticized human rights record. Local laws allow UAE citizens to initiate criminal action against expatriates, including doctors and nurses, and obtain convictions while the accused remain unaware of the allegations. 6 In another analogous, recent high-profile criminal case from the UAE, an Austrian doctor was sentenced, in absentia, to life in prison for premeditated murder. The basis for the charge was that he had given orders not to resuscitate an ill patient who suffered from repeated cardiac arrests. 7

\section{Hazards of a Locum Tenens}

These cases illustrate the hazards of working in countries with less than transparent judicial systems. They are reminiscent of a Libyan situation in 1999 under Muammar Gaddafi's regime. Six Bulgarian medical workers were arrested and sentenced to death on charges of intentionally infecting more than 400 Libyan children with HIV, thus causing AIDS. The accused nurses and the doctor blamed the infection of the children on poor hygiene in the hospital where they worked. Independent medical studies showed that the infections in the hospital predated the arrival of the medical workers by several years. Finally, in 2007, after 8 years in prison, they were released after lengthy negotiations that resulted in payments of millions of dollars from various foreign governments and organizations. The medical workers described being tortured by electric shock, being raped, and being attacked by dogs during their incarceration.8-16

In regard to the current issue concerning Dr. Karabus, in mid-October, with mounting global pressure, the UAE allowed Karabus to leave jail on bail. Apparently, the defense team also was finally permitted access to the girl's medical records. However, the trial has been further postponed to December because the complete hospital files still could not be located.17,18

The case of Cyril Karabus indicates the dangers associated with employment in countries that do not recognize that the practice of medicine cannot guarantee a favorable outcome. This is especially pertinent when patients are very ill with diseases such as cancer. Physicians and nurses in this field may be at risk when working in the UAE if their patients succumb to their illness, especially if the patient's family has influence because of wealth or connections.

Although many countries and organizations have protested Karabus' incarceration, American universities and media have remained mute; yet, several major US universities and hospitals, including but not limited to Johns Hopkins University and the University of Texas MD Anderson Cancer Center, engage in frequent medical exchanges with the UAE, often based on large financial gifts from the sheikh's family. It seems that these institutes, having forged a relationship with the UAE, should have examined the Karabus case and lent their voices to the call to hasten his release. Furthermore, they should have a moral and a legal obligations to warn their faculty that should a patient die, they could be tried and convicted in absentia and without their 
knowledge. It has now been extensively documented that silence and collusion can be bought with large donations. Indeed, in 2011, the director of the London School of Economics was finally forced to resign after dishonoring the school in return for Gaddafi's money. British newspapers also have documented how money, in the guise of philanthropic donations for academic studies, has changed the intellectual climate in universities in the United Kingdom, often to promote a worldview hostile to the West while remaining quiet about injustices elsewhere.19,20

\section{Conclusion}

It is time for American institutions to find their voice and speak up for Cyril Karabus.

Furthermore, faculty must be informed that they could be apprehended and incarcerated on their return to the UAE on the basis of an in absentia verdict. More importantly, serious scrutiny of the effect of foreign philanthropic funding on American academic and medical institutes is long overdue.

Philip R. Cohen, MD

Dermatologist, Bellaire, TX, USA

Razelle Kurzrock, MD

Medical Oncologist, Bellaire, TX, USA

Lawrence Charles Parish, MD, MD (Hon)

Dermatology and Cutaneous Biology

Jefferson Medical College of Thomas Jefferson University

Philadelphia, PA, USA and

Jefferson Medical College of Thomas Jefferson University

Philadelphia, PA, USA

E-mail address: larryderm@yahoo.com

http://dx.doi.org/10.1016/j.clindermatol.2012.11.001

\section{References}

1. Nathanson V. The imprisonment of Cyril Karabus is deplorable andmay affect the subsequent practice of foreign doctors in the UAE. BMJ 2012;345:e6815.

2. Underhill G. "Caring" doctor arrested in transit. Mail \& Guardian (Africa's Best Read) 28 September 2012. http://www.mg.co.za/article/ 2012-09-28-00-caring-doctor-arrested-in-transit.

3. Boseley S. Concern for South African doctor held in Abu Dhabi over mystery conviction. The Guardian 3 October 2012. http://www.guardian.co.uk/world/2012/oct/03/south-african-doctorabu-dhabi.

4. Dubula V, Brockman B, Majola M, Heywood M, Achmat Z. Open letter to minister of international relations: intervene in Karabus case. Treatment Action Campaign 26 September 
2012. http://www.ngopulse.org/blogs/open-letter-minister-international-relationsintervenekarabus-case.

5. WMA General Assembly. WMA resolution in support of progessor Cyril Karabus. World Medical Association. Adopted by the 63rd WMA General Assembly, Bangkok, Thailand, 16 October 2012. http://www.wma.net/en/30publications/10policies/k2/index.html.

6. Fitzgibbon W. Doctor's detention puts UAE justice in the spotlight. The Bureau Of Investigative Journalism 11 October 2012.

http://www.thebureauinvestigates.com/2012/10/11/doctors-detention-puts-uaejustice-in-thespotlight.

7. Euthanasia doctor brands life sentence a farce. Austrian Times 22 October 2012.

http://www.austriantimes.at/news/General_News/2012-10-

22/44946/Euthanasia_Doctor_Brands_Life_Sentence_a_Farce.

8. Ahmad K. US criticizes Bulgarian nurses' conviction. Condemnation for death sentences met by protests in Libya. Lancet 2004;363:1611.

9. Zalon ML. Bulgarian nurses appeal Libyan death sentence. Pa Nurse 2005;60:22.

10. Tsankov N, Kehayov A. Crisis in Libya: doctor and nurses under death sentence. Clin Dermatol 2005;23:527.

11. Butler D. Protests mount against Libyan trial. Nature 2006;443: 612-3.

12. Butler D. Europe condemns Libyan trial verdict. Nature 2007;445:7.

13. Tsankov N. The Libyan AIDS crisis and a miscarriage of justice. Clin Dermatol 2007;25:146.

14. Butler D. Libyan ordeal ends: medics freed. Nature 2007;448:398.

15. van Zyl T. Libya negotiates deal for release of doctor, 5 nurses. CMAJ 2007;177:448. 16. Parish LC. Freedom for the Bulgarian nurses and a Palestinian doctor. Clin Dermatol 2008;26:574.

17. Underhill G. Bail for SA doctor facing manslaughter charge in Abu Dhabi. Mail \& Guardian (Africa's Best Read) 11 October 2012. http://www.mg.co.za/article/2012-10-11-sa-doctor-facingmanslaughtercharge-in-abu-dhabi-granted-bail.

18. Williams M. Karabus granted bail by UAE court. iOL news 12 October 2012. http://www.newsle.com/article/0/39113923. 
19. Gross T. UAE closes Zayed center ("Harvard and the Holocaust" follow-up). Mideast Dispatch Archive 18 August 2003.

http://www.tomgrossmedia.com/mideastdispatches/archives/000229.html.

20. Pollard S. Libya and the LSE: large Arab gifts to universities lead to "hostile" teaching. The Telegraph 3 March 2011.

http://www.telegraph.co.uk/news/worldnews/africaandindianocean/libya/8360103/Libyaand-theLSE-Large-Arab-gifts-to-universities-lead-to-hostile-teaching.

html 